\title{
An Experiment in Solar Design at San Jose State University
}

\section{Jeff Paul \\ Media Services Department San Jose State University}

Dedication ceremonies for the new "solar" Robert D. Clark Library at San Jose State University took place on February 19, 1982. The Library is the first structure in the 18 campus California State University System to incorporate a natural energy system.

The five-story, 125,000-square foot building was designed by Pflueger Architects of San Francisco. Plans for a new library facility at SJSU have been developed and scrapped several times over the past 15 years. Original plans for a nine-story library became plans for an 18-story highrise which was then whittled to twelve stories. Because of inflation, budgetary cutbacks, and high costs for labor and construction materials, only a five-story building was ultimately approved. Neither of the existing libraries at SJSU is large enough to house all campus library collections. The Clark Library doubled the amount of space available for campus library resources and services.

The $\$ 13$ million structure was dedicated in honor of Robert Clark, the University's 18th President. Clark directed the campus master plan in the late 1960s and he was the first to propose the new central library, calling it the "heart of the campus." Funds for the structure were appropriated in 1969 but they were recalled the following year. Ten years passed before funds were again available. Construction began in 1979 and the building was completed in November of 1981.

The Clark Library is unique in that it is totally dependent on solar heating and cooling for internal climate control. The building's solar heating and cooling system was designed to function as a solarassisted system that would be connected to a conventional heating and cooling plant. However, because of cost considerations the backup connection was deleted by the California Department of Finance. In essence, the university was offered a choice between a library without backup support or no library at all. Campus administrators who had been frustrated with over a decade of delays regarding the facility finally decided to accept the proposal hoping to be able to get the backup some time in the future.

Ideally, the natural energy design for heating and cooling is expected to keep the building between 68 and 78 degrees. The temperature in the building was expected to fall within this range $80 \%$ of the time even without the backup system. The facility has massive concrete walls and mirrored windows to minimize heat gain and loss. The concrete works like a sponge to retain heat and minimize thermal changes.

Heating is generated by 147 solar collector panels mounted in three rows on the south side of the building. Water heated by the sun's rays is pumped through the collectors to an insulated 12,000gallon hot water tank in the basement. There fans draw circulating air over hot water pipes to heat the building. The heating system was designed to have a five-day reserve capacity. It should be able to retain heat for up to five completely overcast days.

The cooling system utilizes four 30,000-gallon reservoirs in the basement to cool the air. Water is pumped from these tanks through a cooling tower. This is done in the evening when night air aids the cooling process. There fans draw circulating air over the cool water pipes. Windows are also opened at night to help cool the air in the building.

The heating and cooling systems have both had their share of problems to date. The cooling system was operational three full days in the early summer before it went down. Insulation lining the walls of the reservoirs has broken up and permeated the entire system. The solar panels will have to be flushed to remove the bits of insulation from the system. The reservoirs were also drained and relined with new insulation. During the summer it was not unusual for the temperature in work areas to exceed 82 to 84 degrees. Fortunately the summer was moderate due to volcanic eruptions, good luck, and the Bay Area's generally cool climate.

Heating was a general concern when the building was occupied in January. Apparently the heating process takes a good deal of time in a new facility and the concrete had not been allowed a sufficient amount of time to warm up. During the move into the building it was not unusual for the internal temperature to drop below 60 degrees. This was especially true on the lower floors and in offices on the north side of the building.

SJSU administrators are seeking funds to connect the Clark Library to the campus heating and cooling plant. Current cost estimates for this connection range around $\$ 200,000$. The damage to books and other resources exposed to dramatic fluctuations in temperature over an extended period of time would greatly exceed this sum.

The Clark Library serves as the main undergraduate library in a two-building operation. Resources are divided by high use/low use and by date between the libraries. Frequently used books and books published from 1970 to date are located in the Clark Library. The Clark Library also houses 
most public service departments and periodicals published from 1965 to present. Older, less used, and more scholarly materials are located in the John T. Wahlquist Library. University Librarian
Maureen Pastine devised the high use/low use plan for dividing the collections. The plan was approved by the SJSU Academic Senate before it was implemented.

\section{Research Release Time at}

\section{the University of New Mexico Library}

\section{Diane Stine \\ University of New Mexico Library}

In April 1979 the Ad Hoc Committee to Prepare a Final Report on Faculty Requirements (appointed by the dean of the library) at the University of New Mexico Library issued a document stating that UNM library faculty members have a strong commitment to scholarship and are most valued when they combine outstanding job performance with distinguished contributions in the areas of scholarship and service. This document was accepted by the dean and the library faculty.

In September 1979 another library committee, the Research and Publications Committee, raised the issue of granting release time for research, creative works, and publication. This committee is composed of five to seven librarians appointed by the dean and representatives of the library faculty from individuals who have expressed an interest in serving on it. Members are chosen from all areas of the library and all administrative levels.

By interviewing faculty members the committee soon learned how faculty handled their research responsibilities. Some people ignored the issue and resigned themselves to a tenure denial in the future. Others worked on their research nights and weekends. Some asked the dean for administrative leave for projects, while others took time off without asking anyone's permission. The committee found that the faculty preferred a formal, administratively sanctioned avenue for research release time.

Two possible options were available: 1) Individuals could fill out a leave form similar to one submitted when taking professional leave for a conference; the form could be signed by an immediate supervisor and the assistant dean of the division. Or 2), the committee could monitor a program for release time based on written guidelines accepted by the dean and university faculty.

The committee-monitored program had the advantage of creating support and encouragement to the faculty through contact made between committee members and individuals engaged in research. It also eliminated the objection that people might not use their time productively. Although this approach eliminated the supervisor's input, the committee reasoned that since anyone who could not meet a publication requirement might face unemployment, then a supervisor's inconvenience during an employee's absence for release time was less of a problem than that person's permanent loss.

A leave form provided the easiest way to grant release time. It called less attention to the issue than the committee-monitored approach. The supervisor and assistant dean who sign the form could serve as a source of support and encouragement to the faculty member doing research. On the other hand, they also have the right to refuse leave in cases where they believe time might be wasted or could not be spared.

Committee members and the library administration favored the committee-monitored alternative.

The committee then drafted a plan for a pilot project and sent written guidelines to all faculty. It then accepted applications from individuals desiring professional leave for creative work, research and/or publication. It was felt that only nontenured faculty should be eligible because their professional obligations were more pressing and they lacked the benefit of sabbatical leave.

The length of the project covered twelve months. Applications were limited to proposals which could be completed within six months and another six months were allowed for the submission/review process. All applications contained an outline of the work including the final objective desired (publication, prize, etc.), request for a specific range of release time, and evidence of commitment to the work from the faculty member or an outside agency. Evidence consisted of a literature search, a preliminary draft, preparation of a data collection instrument, collected data, a grant, a letter of interest from a publisher or other source, and a statement of intent to complete the work.

All applications were reviewed using the following criteria: the potential value of the work to the individual and to the target audience; its likelihood of success as measured by a positive review from 